\title{
The Impact of Global Crisis on the Subsidies PAID to Retailers and Wholesalers in Eastern European and Central Asian Countries
}

\author{
Ayse Nilgun BALAS ${ }^{1}$
}

Halil Dincer KAYA ${ }^{2}$

\begin{abstract}
This study examines the impact of the 2008-2009 global crisis on subsidies paid to retailers and wholesalers. The results indicate that a significantly larger proportion of retailers received subsidies after the global crisis. Female ownership and top manager's experience level did not matter in receiving significantly higher subsidies after the global crisis, but firm size, firm type, top manager's gender, and whether or not the firm has an internationally recognized quality certification had made a difference in terms of subsidies received after the crisis. Our results indicate that a significantly larger proportion of wholesalers had received subsidies after the global crisis. While firm size did not matter for wholesalers, firm type, top manager's gender and experience level, whether or not the firm has a female owner, and whether or not the firm has an internationally recognized quality certification made a difference in terms of subsidies received after the crisis.
\end{abstract} Central Asia

Keywords: subsidy, subsidies, retailer, wholesaler, global crisis, Eastern Europe,

JEL classification: K42, M31

DOI: $10.24818 /$ RMCI.2019.1.14

\section{Introduction}

The 2008-2009 global crisis had a considerable adverse effect on most companies, but especially on retailers and wholesalers. As consumers' income levels decreased, their spending at retail stores also decreased. In order to lessen the impact of the global crises on national economy, many governments utilized subsidies (Brautzsch, Günther, Loose, Ludwig, \& Nulsch 2015). Government subsidies can be classified as supply-side subsidies, where the subsidies are applied on the wholesale side of the market to increase supply and reduce private costs, or demand-side subsidies that are targeted towards the consumers to promote demand and lower prices. In this study, our focus is on supply-side subsidies that are directed towards retail and wholesale firms, and subsidies refer to monetary or

\footnotetext{
${ }^{1}$ Ayse Nilgun Balas, Virginia State University, E-mail: abalas@ vsu.edu, Telephone: 804-524-5974, Fax: 804-524-5110

${ }^{2}$ Halil Dincer Kaya, Northeastern State University, E-mail: kaya@nsuok.edu, Telephone: 918-4496572, Fax: 918-449-6019
} 
other resources that a government awards to retail or wholesale firms (Cavusgil, Knight, \& Risenenberger 2012). These supply-side subsidies can be in the form of cash payments, low interest loans, tax credits in the form of property tax exemptions or abatement, tax increment financing, low interest taxable bonds, etc. (Becker 2015; Freedman \& Kuhns 2018; Wild \& Wild 2019). In emerging markets older retailers need government subsidies to update themselves to compete with modern and more organized retail forms (Erkip, Kızılgün, \& Akinci 2014).

Although retailers and wholesalers receive large subsidies from governments empirical research that examines the subsidies given to retailers and wholesalers is scarce. Most of the previous research on subsidies focuses on manufacturing firms and how subsidies helped innovativeness in these firms (García-Quevedo 2004; Hud \& Hussinger 2015). Moreover, most of the current research examines subsidies in developed countries (Zuniga-Vicente, AlonsoBorrego, Forcadell, \& Galan 2014). Government subsidies in response to economic crises are important for retailers and wholesalers in emerging markets due to increased restriction of access to gaining capital (Aristei, Sterlacchini \& Venturini 2017; Brown, Ongena, Popov \& Yeşin 2011; Mateut 2018) and decreasing consumer spending.

This paper contributes to the literature in several ways: First, it empirically examines subsidies provided to retailers and wholesalers in emerging countries of Eastern Europe and Central Asia. Second, it examines how subsidies given to retailers and wholesalers changed after the global crisis. Third, it examines how subsidies given to different subgroups of retailers and wholesalers (based on various firm/owner/manager characteristics) changed after the global crisis.

The remainder of the paper is organized as follows. Section 2 reviews the previous literature. Section 3 presents the dataset and summary statistics. Section 4 presents the analysis of the data. Finally, Section 5 discusses the results and provides a conclusion.

\section{Literature Review}

It is a common practice among governments to provide subsidies to retailers and wholesalers. The news reports are replete with retailers getting large subsidies from governments. Some recent examples are tax subsidies given to Bass Pro Shop (Brantley 2012), Walmart (Resnikoff 2014), and Amazon (Bologna 2017).

There is an extensive research on the role of public subsidies on promoting research and development (R\&D) activities of firms. $R \& D$ is a critical factor that fosters innovation in firms (Brown et al. 2011). The research on role of public subsidies on R\&D activities of firms gave conflicting results (Zuniga-Vicente et al. 2014). One group of scholars found "crowding out" effect of public subsidies on R\&D activities of firms (i.e., Capron \& Van Pottelsberghe 1997; David, Hall \& Toole 2000). In other words, public subsidies replaced the amount of private R\&D spending rather than complimenting it. 
Another group of scholars found that there was weak evidence for crowding out effect (i.e., García-Quevedo 2004; González \& Pazó 2008; ZunigaVicente et al. 2014). González \& Pazó (2008) investigated tax credit and direct subsidies to Spanish manufacturing firms. Their results indicated no evidence of total or partial crowding out effect. The finding of González \& Pazó's (2008) study was supported by meta-analysis conducted by other scholars. In a meta-analysis of 39 studies, García-Quevedo (2004) found "very weak evidence" for crowding out effect. In a more comprehensive meta-analysis, Zuniga-Vicente et al. (2014) examined 77 empirical studies and found inconclusive result. They suggested that this inconclusive result was due to difference in development levels of countries included in the studies included in their meta-analysis. Most of the research in their sample for the meta-analysis focused on the US and developed countries in the EU. They stated that using firm-level data rather than aggregate data also caused the inconclusive result. Moreover, most of the studies in their sample focused on manufacturing firms, neglecting other types of firms. Finally, they expressed that most studies were cross-sectional rather than longitudinal and the effects of the subsidies might only be observed after a time lag.

Later studies using more sophisticated methodologies for analysis and sampling found no crowding out effect. Becker (2015), based on review of previous literature, categorized subsidies in three categories: tax credits and direct subsidies, support of university research and formation of highly-skilled human capital, and support of formal R\&D across a variety of institutions. She posited that sample selection bias in earlier studies was the main cause for crowding out effect. She also argued that newer econometric methodologies controlled for such bias in sampling. Her review of more recent research that used newer econometric methodologies did not substantiate crowding out effect. Becker's (2015) argument for no crowding out effect was supported by later empirical studies. Aristei et al. (2017) studied the role of direct R\&D subsidies given by five larger EU countries (France, Germany, Italy, Spain, and the UK) by a firm level analysis. Their results indicated no support for crowding out effect. Mateut (2018) investigated the role of public subsidies and firm innovativeness on 30 Eastern European and Central Asian countries. They found a positive correlation between firm innovativeness and government subsidies. They emphasized that this result was especially true for firms with financial constraints.

One of the few studies that examined subsidies given to retailers is by Shoag \& Veuger (2018). In their study, they investigated the spillovers produced by big-box retail stores in the US. Their sample consisted of bankrupt chain retailers, such as bookstores, department stores, electronic stores, and houseware stores. After the big-box retailer left the market the nearby businesses were negatively affected. Some of them closed down, while others hired fewer employees. In order to prevent these spillover effects, some local governments provided retail subsidies. However, these subsidies given by local governments to big-box retailers caused the crowding out effect. Big-box retailers relied on local government subsidies rather than the mechanisms provided by the private sector 
that dealt with these spillover effects in the form of heavily reduced rental rates or no rent at all.

\section{Data}

In this current study, BEEPSII and BEEPSIV surveys (Business Environment and Enterprise Performance Surveys) were utilized to examine the impact of the global crisis on subsidies paid to retailers. These surveys, conducted by the European Bank for Reconstruction and Development and the World Bank, cover businesses in Eastern Europe and Central Asia. These surveys were used in previous studies (i.e., Mateut 2018). The 2008 survey results were compared to those of 2013. The 2008 survey results represent the "pre-crisis period," and the 2013 survey results represent the "post-crisis period".

The twenty-nine countries that are included in the 2008 survey are: Albania, Armenia, Azerbaijan, Belarus, Bosnia and Herzegovina, Bulgaria, Croatia, Czech Republic, Estonia, FYR Macedonia, Georgia, Hungary, Kazakhstan, Kosovo, Kyrgyz Republic, Latvia, Lithuania, Moldova, Mongolia, Montenegro, Poland, Romania, Serbia, Slovak Republic, Slovenia, Tajikistan, Turkey, Ukraine, and Uzbekistan.

The main research question is: "Over the last three years has this establishment received any subsidies from the national, regional or local governments or European Union sources?" In the surveys, "Yes" is coded as " 1 " and "No" is coded as " 2 ". These surveys include information on retailers' and wholesalers' size, firm type, the gender of the top manager, whether or not the firm is part of a larger firm, whether or not at least one owner is female, the experience level of the top manager, and whether or not the firm has an internationally recognized quality certification.

Table 1 shows the summary statistics for years 2008 and 2013. Panel A shows the statistics for all retailers in the sample. The mean value for all firms in 2008 is 1.941 , while it is 1.926 in 2013 . These results indicate that more retailers in Eastern Europe and Central Asia received subsidies in 2013 when compared to 2008.

Panel B differentiates between small, medium-sized, and larger retailers (i.e. 5-19 employees, 20-99 employees, and employees >99) and presents the summary statistics for each size group in 2008 and in 2013. For small and midsized retailers, the mean values are smaller in 2013 when compared to 2008. The mean value for small retailers is 1.954 in 2008 compared to 1.946 in 2013 . The mean value for medium-sized retailers is 1.943 in 2008, while it is 1.894 in 2013. These findings suggest that, for small and mid-sized retailers, there are more businesses that received subsidies in 2013 when compared to 2008. However, the opposite is true for larger retailers. The mean value for larger retailers is 1.900 in 2008 while it is 1.905 in 2013. This finding indicates that less number of larger retailers received subsidies in 2013 when compared to 2008. 
Subsidies to Retailers from Govts/EU over the Last 3 Years

Table 1

\begin{tabular}{|c|c|c|c|c|c|c|}
\hline & \multicolumn{3}{|c|}{2008} & \multicolumn{3}{|c|}{2013} \\
\hline & $\mathbf{N}$ & Mean & Std & $\mathbf{N}$ & Mean & Std \\
\hline \multicolumn{7}{|l|}{ Panel A. All Firms } \\
\hline all firms & 2,429 & 1.94 & 0.24 & 2,860 & 1.93 & 0.26 \\
\hline \multicolumn{7}{|l|}{ Panel B. Firm Size } \\
\hline employees5-19 & 1,251 & 1.95 & 0.21 & 1,697 & 1.95 & 0.23 \\
\hline employees20-99 & 749 & 1.94 & 0.23 & 729 & 1.89 & 0.31 \\
\hline employees $>99$ & 429 & 1.90 & 0.30 & 252 & 1.90 & 0.29 \\
\hline \multicolumn{7}{|l|}{ Panel C. Part of a Larger Firm } \\
\hline part of a larger firm & 275 & 1.93 & 0.25 & 253 & 1.92 & 0.27 \\
\hline not part of a larger firm & 2,154 & 1.94 & 0.23 & 2,607 & 1.93 & 0.26 \\
\hline \multicolumn{7}{|l|}{ Panel D. Firm Type } \\
\hline shareholding firm trading in the stock market & 170 & 1.93 & 0.26 & 46 & 1.91 & 0.28 \\
\hline shareholding firm shares traded privately & 1,373 & 1.94 & 0.24 & 2,269 & 1.92 & 0.26 \\
\hline sole proprietorship & 477 & 1.97 & 0.16 & 327 & 1.93 & 0.25 \\
\hline partnership & 77 & 1.96 & 0.19 & 89 & 1.93 & 0.25 \\
\hline limited partnership & 221 & 1.90 & 0.31 & 38 & 1.95 & 0.23 \\
\hline other & 104 & 1.93 & 0.25 & 88 & 1.95 & 0.21 \\
\hline \multicolumn{7}{|l|}{ Panel E. Female Owner } \\
\hline one or more female owner & 1,065 & 1.93 & 0.25 & 1,182 & 1.91 & 0.29 \\
\hline no female owner & 1,316 & 1.95 & 0.22 & 1,643 & 1.94 & 0.24 \\
\hline \multicolumn{7}{|l|}{ Panel F. Experienced Top Manager } \\
\hline top manager with $0-15$ years of experience & 1,483 & 1.95 & 0.21 & 1,398 & 1.94 & 0.24 \\
\hline top manager with $>15$ years of experience & 897 & 1.93 & 0.26 & 1,369 & 1.91 & 0.28 \\
\hline \multicolumn{7}{|l|}{ Panel G. Top Manager Female } \\
\hline top manager female & 674 & 1.94 & 0.23 & 816 & 1.94 & 0.24 \\
\hline top manager not female & 1,752 & 1.94 & 0.24 & 2,029 & 1.92 & 0.27 \\
\hline \multicolumn{7}{|l|}{ Panel H. Quality Certification } \\
\hline $\begin{array}{l}\text { firm without an intl recog. quality } \\
\text { certification }\end{array}$ & 2,010 & 1.95 & 0.21 & 2,325 & 1.94 & 0.24 \\
\hline firm with an intl recog. quality certification & 340 & 1.88 & 0.33 & 468 & 1.88 & 0.33 \\
\hline
\end{tabular}

Note: "Yes" is 1, "No" is 2.

Panel C compares retailers that are part of a larger firm and retailers that are not, and illustrates the statistics for each size group for 2008 and 2013. The results indicate that for both groups, the mean values are smaller in 2013 when compared to 2008. The mean value for retailers that are part of a larger firm is 1.931 in 2008, while it is 1.921 in 2013. The mean value for retailers that are not part of a larger firm is 1.942 in 2008 , while it is 1.927 in 2013. These findings demonstrate that there are more businesses that received subsidies in 2013 when compared to 2008 . 
Panel D differentiates between different types of retailers and shows the statistics for each type group in 2008 and in 2013. The results indicate that, except for "limited partnerships" and "other" type of retailers, the mean values are smaller in 2013 when compared to 2008. These findings demonstrate that besides limited partnerships and firms classified as "other types" more retailers received subsidies in 2013 when compared to 2008.

Panel E compares retailers with at least one female owner to retailers without any female owner. Panel $F$ differentiates between retailers with less experienced top managers (i.e. top managers with a total experience of 15 years or less) and retailers with more experienced top managers (i.e. top manager with more than 15 years of experience). Panel G differentiates between retailers with a female top manager and retailers with a male top manager. The results demonstrate that for all of these subgroups the mean values are smaller in 2013 when compared to 2008. That is, for all of these subgroups there are more businesses that received subsidies in 2013 when compared to 2008.

Panel $\mathrm{H}$ differentiates between retailers with an internationally recognized quality certification (i.e. ISO 9000, 9002, 14000, etc.) and retailers without an internationally recognized quality certification, and illustrates the statistics for each group in 2008 and in 2013. The results demonstrate that the mean values are smaller in 2013 when compared to 2008 for retailers without an internationally recognized quality certificate. However, for retailers with a quality certificate the mean values are higher in 2013 when compared to 2008. These findings indicate that there are more retailers without a quality certificate that received subsidies in 2013 when compared to 2008 . On the other hand, there are fewer retailers with a quality certificate that received subsidies in 2013 when compared to 2008.

Table 2 shows the summary statistics for the wholesalers for years 2008 and 2013. Panel A shows the statistics for all wholesalers in the sample. The mean value for the main "subsidies" question in 2008 is 1.937, while it is 1.908 in 2013. Lower values mean more wholesalers received subsidies since "Yes" is coded as " 1 " and "No" is coded as " 2 ". Therefore, it is concluded that there are more wholesalers in Eastern Europe and Central Asia that received subsidies in 2013 when compared to 2008.

Panel B differentiates between small, medium-sized, and larger wholesalers (i.e. 5-19 employees, 20-99 employees, and firms with employees larger than 99). The results indicate that, for all size subgroups, the mean values are smaller in 2013 when compared to 2008. The mean value for small wholesalers is 1.953 in 2008 while it is 1.920 in 2013 . The mean value for medium-sized wholesalers is 1.945 in 2008 while it is 1.896 in 2013. The mean value for larger wholesalers is 1.879 in 2008 while it is 1.804 in 2013. These findings demonstrate that, for all size subgroups, there are more wholesalers that received subsidies in 2013 when compared to 2008.

Panel C compares wholesalers that are part of a larger firm to wholesalers that are not. For both groups the mean values are smaller in 2013 when compared to 2008. The mean value for wholesalers that are part of a larger firm is 1.910 in 
2008, while it is 1.909 in 2013. The mean value for wholesalers that are not part of a larger firm is 1.940 in 2008, while it is 1.908 in 2013. These findings indicate that, for both groups, more wholesalers received subsidies in 2013 when compared to 2008 .

Subsidies to Wholesalers from Govts/EU over the Last 3 Years

\begin{tabular}{|c|c|c|c|c|c|c|}
\hline & \multicolumn{3}{|c|}{2008} & \multicolumn{3}{|c|}{2013} \\
\hline & $\mathbf{N}$ & Mean & Std & $\mathbf{N}$ & Mean & Std \\
\hline \multicolumn{7}{|l|}{ Panel A. All Firms } \\
\hline all firms & 757 & 1.94 & 0.24 & 964 & 1.91 & 0.29 \\
\hline \multicolumn{7}{|l|}{ Panel B. Firm Size } \\
\hline employees5-19 & 364 & 1.95 & 0.21 & 616 & 1.92 & 0.27 \\
\hline employees20-99 & 253 & 1.94 & 0.23 & 251 & 1.90 & 0.31 \\
\hline employees $>99$ & 140 & 1.88 & 0.33 & 51 & 1.80 & 0.40 \\
\hline \multicolumn{7}{|l|}{ Panel C. Part of a Larger Firm } \\
\hline part of a larger firm & 89 & 1.91 & 0.29 & 99 & 1.91 & 0.29 \\
\hline not part of a larger firm & 668 & 1.94 & 0.24 & 865 & 1.91 & 0.29 \\
\hline \multicolumn{7}{|l|}{ Panel D. Firm Type } \\
\hline $\begin{array}{l}\text { shareholding firm trading in the } \\
\text { stock market }\end{array}$ & 42 & 1.90 & 0.30 & 11 & 1.91 & 0.30 \\
\hline $\begin{array}{l}\text { shareholding firm shares traded } \\
\text { privately }\end{array}$ & 469 & 1.94 & 0.24 & 852 & 1.90 & 0.30 \\
\hline sole proprietorship & 116 & 1.92 & 0.27 & 53 & 1.92 & 0.27 \\
\hline partnership & 25 & 1.96 & 0.20 & 29 & 1.97 & 0.19 \\
\hline limited partnership & 75 & 1.96 & 0.20 & 5 & 2.00 & 0.00 \\
\hline other & 30 & 1.93 & 0.25 & 14 & 2.00 & 0.00 \\
\hline \multicolumn{7}{|l|}{ Panel E. Female Owner } \\
\hline one or more female owner & 265 & 1.91 & 0.29 & 295 & 1.89 & 0.31 \\
\hline no female owner & 475 & 1.95 & 0.21 & 649 & 1.91 & 0.28 \\
\hline \multicolumn{7}{|l|}{\begin{tabular}{|l|} 
Panel F. Experienced Top \\
Manager \\
\end{tabular}} \\
\hline $\begin{array}{l}\text { top manager with } 0-15 \text { years of } \\
\text { experience }\end{array}$ & 411 & 1.96 & 0.20 & 493 & 1.91 & 0.28 \\
\hline $\begin{array}{l}\text { top manager with }>15 \text { years of } \\
\text { experience }\end{array}$ & 329 & 1.91 & 0.28 & 447 & 1.90 & 0.30 \\
\hline \multicolumn{7}{|l|}{ Panel G. Top Manager Female } \\
\hline top manager female & 124 & 1.94 & 0.25 & 179 & 1.92 & 0.28 \\
\hline top manager not female & 631 & 1.94 & 0.24 & 781 & 1.91 & 0.29 \\
\hline \multicolumn{7}{|l|}{ Panel H. Quality Certification } \\
\hline $\begin{array}{l}\text { firm without an intl recog. quality } \\
\text { certification }\end{array}$ & 552 & 1.96 & 0.20 & 703 & 1.94 & 0.24 \\
\hline $\begin{array}{l}\text { firm with an intl recog. quality } \\
\text { certification }\end{array}$ & 186 & 1.87 & 0.34 & 236 & 1.84 & 0.37 \\
\hline
\end{tabular}

Note: "Yes" is 1, "No" is 2. 
Panel D distinguishes different types of wholesalers based on firm type, and illustrates the statistics for each firm type for 2008 and 2013. Interestingly, only the mean values for privately traded wholesalers are smaller in 2013 when compared to 2008. For all other types of firms the mean values are larger in 2013 when compared to 2008. These findings indicate that, only for wholesalers that have their shares traded privately, there are more businesses that received subsidies in 2013 when compared to 2008. For all other groups, there are fewer wholesalers that received subsidies in 2013 when compared to 2008.

Panel E differentiates between wholesalers with at least one female owner and wholesalers without any female owner. Panel F differentiates between wholesalers with less experienced top managers (i.e. top managers with a total experience of 15 years or less) and wholesalers with more experienced top managers (i.e. top manager with more than 15 years of experience). Panel G differentiates between wholesalers with a female top manager and wholesalers with a male top manager. Panel $\mathrm{H}$ differentiates between wholesalers with an internationally recognized quality certification (i.e. ISO 9000, 9002, 14000, etc.) and wholesalers without an internationally recognized quality certification. The results indicate that for all of these subgroups the mean values are smaller in 2013 when compared to 2008. In other words, the results demonstrate that there are more wholesalers that received subsidies in 2013 when compared to 2008 based on female ownership, experience of top managers, female top manager, and ownership of quality certification.

In the following section, the 2008 survey results are compared to those of 2013 survey results using Mann-Whitney-Wilcoxon tests. First, the results for 2008 are compared to the results of 2013 for all retailers, and then for all wholesalers. Then, comparisons are made for each subgroup (i.e. firm-type subgroups, firm-size subgroups, etc.).

\section{Empirical Results}

Table 3 compares the subsidies paid to all of the retailers in the sample during the three-year period ending in 2008 versus in 2013. The mean score is 1.941 in 2008 versus 1.926 in 2013 , meaning that there is a decline in the score. A decline in this score indicates that more firms had received subsidies from their governments or from EU in 2013 versus in 2008. This difference is statistically significant $(\mathrm{p}=0.0153)$.

Subsidies to Retailers from Govts/EU over the Last 3 Years

Table 3

\begin{tabular}{|l|c|c|c|}
\hline \multicolumn{5}{|c|}{ Wilcoxon Test } \\
\hline \multicolumn{4}{|c|}{} \\
\hline all & $\mathbf{2 0 0 8}$ & $\mathbf{2 0 1 3}$ & p-value \\
\hline
\end{tabular}

Note: "Yes" is 1 , "No" is 2. 
Table 4 compares the subsidies paid to all wholesalers in the sample during the three-year period ending in 2008 versus in 2013. The mean score is 1.937 in 2008 versus 1.908 in 2013, meaning that there is a decline in the score. A decline in the score indicates that more firms had received subsidies from their governments or from EU in 2013 versus in 2008. The difference is statistically significant $(\mathrm{p}=0.0139)$.

Subsidies to Wholesalers from Govts/EU over the Last 3 Years

\begin{tabular}{|l|c|c|c|}
\hline \multicolumn{4}{|c}{ Table 4 } \\
\hline \multicolumn{4}{|c|}{ Wilcoxon Test } \\
\hline all & $\mathbf{2 0 0 8}$ & $\mathbf{2 0 1 3}$ & p-value \\
\hline
\end{tabular}

Note: "Yes" is 1, "No" is 2.

Table 5 studies the retailers in terms of firm size and firm type. It investigates whether the subsidies had increased for firms of different sizes (firms with 5-19 employees, firms with 20-99 employees, and firms with more than 99 employees) and for firm with different types (whether the firm is part of a larger firm and whether the firm is a shareholding firm trading in the stock market, a shareholding firm whose shares are traded privately, a sole proprietorship, etc.).

Our results reveal that only mid-sized retailers, firms with 20-99 employees, were affected positively. Significantly more firms in this size group received subsidies after the global crisis. For firms with 20-99 employees, while the mean score is 1.943 in 2008, it is 1.894 in 2013. This drop (which indicates more firms receiving subsidies) is statistically significant ( $\mathrm{p}=0.0003)$.

\section{Subsidies to Retailers (Firm Size/Type Subgroups)}

\begin{tabular}{|c|c|c|c|}
\hline \multicolumn{4}{|c|}{ Wilcoxon Test } \\
\hline & 2008 & 2013 & p-value \\
\hline employees 5-19 & 1.954 & 1.946 & 0.1447 \\
\hline employees 20-99 & 1.943 & 1.894 & 0.0003 \\
\hline employees $>99$ & 1.900 & 1.905 & 0.4165 \\
\hline part of a larger firm & 1.931 & 1.921 & 0.3314 \\
\hline not part of a larger firm & 1.942 & 1.927 & 0.0151 \\
\hline shareholding firm trading in the stock market & 1.929 & 1.913 & 0.3549 \\
\hline shareholding firm shares traded privately & 1.937 & 1.924 & 0.0667 \\
\hline sole proprietorship & 1.975 & 1.933 & 0.0018 \\
\hline partnership & 1.961 & 1.933 & 0.2116 \\
\hline limited partnership & 1.896 & 1.947 & 0.1617 \\
\hline other & 1.933 & 1.955 & 0.2597 \\
\hline
\end{tabular}

Note: "Yes" is 1, "No" is 2 
On the other hand, for firms with 5-19 employees, while the mean score is 1.954 in 2008 , it is 1.946 in 2013 . This change is not statistically significant $(\mathrm{p}=0.1447)$. Also, for firms with more than 99 employees, while the mean score is 1.900 in 2008 , it is 1.905 in 2013 . This change is also not statistically significant $(\mathrm{p}=0.4165)$.

Table 5 also shows that whether the firm is part of a larger firm or not made a difference in terms of subsidies paid after the global crisis. While there is no significant change in the proportion of firms that are part of a larger firm who received subsidies from 2008 to 2013, more firms that are not part of a larger firm had received subsidies in 2013 versus in 2008. For firms that are part of a larger firm, while the mean score is 1.931 in 2008, it is 1.921 in 2013. This change is not statistically significant $(\mathrm{p}=0.3314)$. On the other hand, for firms that are not part of a larger firm, while the mean score is 1.942 in 2008, it is 1.927 in 2013. This change is statistically significant $(\mathrm{p}=0.0151)$.

Table 5 shows that more sole proprietorships and more firms with shares that are traded privately had received subsidies in 2013 when compared to 2008 . For sole proprietorships, while the mean score is 1.975 in 2008, it is 1.933 in 2013. This change is statistically significant $(\mathrm{p}=0.0018)$. For firms whose shares are traded privately, while the mean score is 1.937 in 2008, it is 1.924 in 2013. This change is also statistically significant $(\mathrm{p}=0.0667)$.

On the other hand, the change in the proportion of firms receiving subsidies from 2008 to 2013 in the other groups (firms whose shares are trading in the stock market, partnerships, limited partnerships, and other firms) is not statistically significant. It can be concluded that only certain types of firms had benefited during this period.

Table 6 examines the wholesalers and tests to see whether the subsidies had increased for all firm size groups (firms with 5-19 employees, firms with 20-99 employees, and firms with more than 99 employees) and for all firm types (whether the firm is part of a larger firm and whether the firm is a shareholding firm trading in the stock market, a shareholding firm whose shares are traded privately, a sole proprietorship, etc.).

\section{Subsidies to Wholesalers (Firm Size/Type Subgroups)}

\begin{tabular}{|c|c|c|c|}
\hline \multicolumn{4}{|c|}{ Wilcoxon Test } \\
\hline & 2008 & 2013 & p-value \\
\hline employees5-19 & 1.953 & 1.920 & 0.0238 \\
\hline employees20-99 & 1.945 & 1.896 & 0.0227 \\
\hline employees $>99$ & 1.879 & 1.804 & 0.0961 \\
\hline part of a larger firm & 1.910 & 1.909 & 0.4914 \\
\hline not part of a larger firm & 1.940 & 1.908 & 0.0092 \\
\hline shareholding firm trading in the stock market & 1.905 & 1.909 & 0.4914 \\
\hline shareholding firm shares traded privately & 1.938 & 1.903 & 0.0132 \\
\hline sole proprietorship & 1.922 & 1.925 & 0.4824 \\
\hline
\end{tabular}




\begin{tabular}{|l|l|l|l|}
\hline partnership & 1.960 & 1.966 & 0.4683 \\
\hline limited partnership & 1.960 & 2.000 & 0.3362 \\
\hline other & 1.933 & 2.000 & 0.1729 \\
\hline
\end{tabular}

Note: "Yes" is 1, "No" is 2.

Our results show that all size groups (firms with 5-19 employees, firms with 20-99 employees, and firms with more than 99 employees) are affected similarly. Significantly more firms in each size group had received subsidies after the global crisis. For firms with 5-19 employees, while the mean score is 1.953 in 2008, it is 1.920 in 2013. This drop (which indicates more firms receiving subsidies) is statistically significant $(\mathrm{p}=0.0238)$. For firms with $20-99$ employees, while the mean score is 1.945 in 2008 , it is 1.896 in 2013 . This change is also statistically significant $(\mathrm{p}=0.0227)$. For firms with more than 99 employees, while the mean score is 1.879 in 2008 , it is 1.804 in 2013 . This change is also statistically significant $(\mathrm{p}=0.0961)$.

Table 6 also shows that whether the firm is part of a larger firm or not made a difference in terms of subsidies paid after the global crisis. While there is no significant change in the proportion of firms that are part of a larger firm who received subsidies from 2008 to 2013, more firms that are not part of a larger firm had received subsidies in 2013 versus in 2008. For firms that are part of a larger firm, while the mean score is 1.910 in 2008 , it is 1.909 in 2013. This change is not statistically significant $(\mathrm{p}=0.4914)$. On the other hand, for firms that are not part of a larger firm, while the mean score is 1.940 in 2008, it is 1.908 in 2013. This change is statistically significant $(\mathrm{p}=0.0092)$.

Table 6 illustrates more firms with shares that are traded privately had received subsidies in 2013 when compared to 2008. For firms whose shares are traded privately, while the mean score is 1.938 in 2008, it is 1.903 in 2013. This change is statistically significant $(\mathrm{p}=0.0132)$.

On the other hand, the change in the proportion of firms receiving subsidies from 2008 to 2013 in the other groups (firms whose shares are trading in the stock market, sole proprietorships, partnerships, limited partnerships, and other firms) is not statistically significant. It can be concluded that only certain types of firms had benefited during this period.

Table 7 examines whether female ownership or female managers made a difference for the retailers. For retailers it did not matter much whether the firm has a female owner or not. The proportion of firms receiving subsidies in both groups (firms with at least one female owner and firms with no female owner) had increased significantly. While the mean score for firms with one or more female owner is 1.931 in 2008 , it is 1.909 in 2013 . The difference is statistically significant $(\mathrm{p}=0.0337)$. While the mean score for firms with no female owner is 1.951 in 2008, it is 1.939 in 2013 . This difference is also statistically significant ( $\mathrm{p}=0.0780)$.

$24 \quad$ Review of International Comparative Management

Volume 20, Issue 1, March 2019 
Subsidies to Retailers (Female Owner/Manager Subgroups)

Table 7

\begin{tabular}{|l|c|c|c|}
\hline \multicolumn{4}{|c|}{ Wilcoxon Test } \\
\hline & $\mathbf{2 0 0 8}$ & $\mathbf{2 0 1 3}$ & p-value \\
\hline one or more female owner & 1.931 & 1.909 & 0.0337 \\
\hline no female owner & 1.951 & 1.939 & 0.0780 \\
\hline top manager female & 1.942 & 1.936 & 0.3192 \\
\hline top manager not female & 1.941 & 1.923 & 0.0147 \\
\hline
\end{tabular}

Note: "Yes" is 1 , "No" is 2.

The table also shows that, for retailers, whether the firm has a female top manager or not did actually matter in terms of the change in subsidies after the global crisis. For the firms that has a female top manager, the proportion of firms that receive subsidies had not increased significantly. While the mean score for firms with a female top manager is 1.942 in 2008, it is 1.936 in 2013. This difference is not statistically significant $(\mathrm{p}=0.3192)$. On the other hand, for the firms that has a male top manager, the proportion of firms that receive subsidies had increased significantly. While the mean score for firms without a female top manager is 1.941 in 2008 , it is 1.923 in 2013 . This difference is statistically significant $(\mathrm{p}=0.0147)$.

Table 8 examines whether female ownership or female managers made a difference for the wholesalers. For wholesalers, whether the firm has a female owner or not did actually matter in terms of the change in subsidies after the global crisis. For the firms that has a female owner, the proportion of firms that receive subsidies had not increased significantly. While the mean score for firms with a female owner is 1.909 in 2008, it is 1.892 in 2013. This difference is not statistically significant $(\mathrm{p}=0.2407)$. On the other hand, for the firms that does not have a female owner, the proportion of firms that receive subsidies had increased significantly. While the mean score for firms without a female owner is 1.952 in 2008 , it is 1.914 in 2013 . This difference is statistically significant ( $\mathrm{p}=0.0071)$.

\section{Subsidies to Wholesalers (Female Owner/Manager Subgroups)}

\begin{tabular}{|l|c|c|c|}
\multicolumn{3}{|c|}{ Wilcoxon Test } \\
\hline & $\mathbf{2 0 0 8}$ & $\mathbf{2 0 1 3}$ & p-value \\
\hline one or more female owner & 1.909 & 1.892 & 0.2407 \\
\hline no female owner & 1.952 & 1.914 & 0.0071 \\
\hline top manager female & 1.935 & 1.916 & 0.2674 \\
\hline top manager not female & 1.937 & 1.905 & 0.0158 \\
\hline
\end{tabular}

Note: "Yes" is 1 , "No" is 2

The table also shows that, for wholesalers, whether the firm has a female top manager or not did actually matter in terms of the change in subsidies after the global crisis. For the firms that has a female top manager, the proportion of firms 
that receive subsidies had not increased significantly. While the mean score for firms with a female top manager is 1.935 in 2008, it is 1.916 in 2013. This difference is not statistically significant $(\mathrm{p}=0.2674)$. On the other hand, for the firms that has a male top manager, the proportion of firms that receive subsidies had increased significantly. While the mean score for firms without a female top manager is 1.937 in 2008 , it is 1.905 in 2013 . This difference is statistically significant $(\mathrm{p}=0.0158)$.

Table 9 examines whether top manager's experience made a difference for the retailers. The results indicate that top manager's experience does not matter for retailers. The proportion of firms receiving subsidies in both groups (i.e. both firms with a relatively less experienced top manager and firms with a relatively more experienced top manager) had significantly increased after the global crisis. While the mean score for firms with a relatively less experienced top manager is 1.951 in 2008 , it is 1.938 in 2013. The difference is statistically significant $(\mathrm{p}=0.0633$ ). Similarly, while the mean score for firms with a relatively more experienced top manager is 1.930 in 2008 , it is 1.912 in 2013 . This difference is also statistically significant $(\mathrm{p}=0.0684)$.

\section{Subsidies to Retailers (Experience/Quality Subgroups)}

\begin{tabular}{|l|c|c|c|}
\multicolumn{4}{|c|}{ Wilcoxon Test } \\
\hline
\end{tabular}

The table also illustrates whether the retailers have an internationally recognized quality certification or not did actually matter. The proportion of firms receiving subsidies in the first group (i.e. firms without an internationally recognized quality certificate) had increased significantly. While the mean score for firms without a quality certification is 1.953 in 2008, it is 1.936 in 2013. This difference is statistically significant $(\mathrm{p}=0.0067)$. On the other hand, the proportion of firms receiving subsidies in the second group (i.e. firms with an internationally recognized quality certificate) had not increased significantly. While the mean score for firms with a quality certification is 1.876 in 2008, it is 1.878 in 2013. This difference is not statistically significant $(\mathrm{p}=0.4705)$.

Table 10 examines whether top manager's experience made a difference for the wholesalers. The results indicate that top manager's experience matters. The proportion of firms receiving subsidies in the first group (i.e. firms with a less experienced top manager) had increased significantly. While the mean score for firms in this group is 1.956 in 2008, it is 1.913 in 2013. This difference is statistically significant $(\mathrm{p}=0.0048)$. On the other hand, the results indicate that the proportion of firms receiving subsidies in the second group (i.e. firms with a more 
experienced top manager) had not increased significantly. While the mean score for firms in this group is 1.912 in 2008, it is 1.902 in 2013. This difference is not statistically significant $(\mathrm{p}=0.3140)$.

\section{Subsidies to Wholesalers (Experience/Quality Subgroups)}

\begin{tabular}{|l|c|c|c|}
\multicolumn{4}{|c|}{ Wilcoxon Test } \\
\hline
\end{tabular}

Note: "Yes" is 1, "No" is 2.

Table 10 also demonstrates that whether the wholesalers have internationally recognized quality certifications or not did actually matter. The proportion of firms receiving subsidies in the first group (i.e. firms without an internationally recognized quality certificate) had increased significantly. While the mean score for firms without a quality certification is 1.958 in 2008 , it is 1.936 in 2013. This difference is statistically significant $(\mathrm{p}=0.0414)$. On the other hand, the proportion of firms receiving subsidies in the second group (i.e. firms with an internationally recognized quality certificate) had not increased significantly. While the mean score for firms with a quality certification is 1.871 in 2008 , it is 1.839 in 2013 . This difference is not statistically significant $(\mathrm{p}=0.1789)$.

\section{Conclusion}

As capital markets in emerging markets of Eastern Europe and Central Asia are less mature, government subsidies play an important role for private firms to access much needed capital, especially when the retailers and wholesalers are affected by an economic crisis (Brown et al. 2011; Mateut 2018). However, governments restrict their financial support to retailers and wholesalers as their tax income decreases due to the economic crisis (Becker 2015). Our results indicate support for this view that governments provide less subsidies to retailers and wholesalers during economic crisis.

Detailed analysis revealed that mid-size retailers received more subsidies after the crisis, while all sizes of wholesalers received more subsidies after the crisis. Retailers and wholesalers that were not part of a larger firm received more subsidies after the crisis. Retailers that were privately traded or organized as sole proprietorship received more subsidies after the crisis, while only the wholesalers that had their shares traded privately received more subsidies after the 2008-2009 economic crisis. These results, overall, support the view that the governmental policymakers support small and medium-size enterprises in developing countries as they believe these firms have inadequate access to external finance (Beck, Demirgüç-Kunt, \& Maksimovic 2008). 
When it was investigated whether the gender of owner or top manager impacted the level of subsidies received by retailers and wholesalers, the results indicate that retailers with and without a female owner both received more subsidies after the crisis. Retailers that did not have a female top manager received more subsidies after the crisis while retailers with female top managers did not. Wholesalers that did not have any female owner or a top female manager received more subsidies after the crisis. These results indicate that gender of the owner was an important determinant for wholesalers, while it wasn't as significant for retailers.

Regardless of the experience level of top manager, all retailers received more subsidies after the economic crisis. However, for wholesalers, top manager's experience made a difference. Only wholesalers with less experienced top managers received more subsidies. These results are contradictory to the literature that posits that the more experienced the top manager is, the more aptly he would be reacting to the economic conditions based on the upper echelons theory (Cucculelli \& Bettinelli 2016; Yunlu \& Murphy 2012).

It is also important to note that while retailers and wholesalers without an internationally recognized quality certification received more subsidies after the crisis, retailers and wholesalers with an internationally recognized quality certification did not. Future studies are needed to understand how firm/owner/manager characteristics affect the size of subsidies received by firms.

\section{References}

Aristei, D., Sterlacchini, A. \& Venturini, F., 2015. Effectiveness of $R \& D$ subsidies during the crisis: Firm level evidence across EU countries. Economics of Innovation and New Technology, 26(6), pp. 554-573.

Beck, T. Demirgüç-Kunt, A. \& Maksimovic, V., 2008. Financing patterns around the world: Are small firms different? Journal of Financial Economics, 89(3), pp. 467-487.

Becker, B., 2015. Public $R \& D$ policies and private $R \& D$ investment: A survey of the empirical evidence. Journal of Economic Surveys, 29(5), pp. 917-942.

Bologna, M.J., 2017. Amazon Close to Breaking Wal-Mart Record for Subsidies [Online] Available at https://www.bna.com/amazon-close-breakingn57982085432/ [Accessed February 20, 2019].

Brantley, M., 2012. Bass Pro - and con on government subsidies for retailers. [Online] Available at https://www.arktimes.com/ArkansasBlog/archives /2012/08/13/bass-pro-and-con-on-government-subsidies-for-retailers [Accessed February 20, 2019]

Brown, M. Ongena, S. Popov, A. \& Yeşin, P., 2011. Who needs credit and who gets credit in Eastern Europe? Economic Policy, 26(65), 93-130. 
Brautzsch, H.-U. Günther, J. Loose, B. Ludwig, U. \& Nulsch, N., 2015. Can R\&D subsidies counteract the economic crisis? - Macroeconomic effects in Germany. Research Policy, 44(3), 623-633.

Capron, H. \& Van Pottelsberghe, B., 1997. Public support to business R\&D: a survey and some new quantitative evidence in: OECD, Policy evaluation in innovation and technology. Towards best practices. Paris: Organisation for Economic Cooperation and Development, pp. 171-188.

Cavusgil, S.T. Knight, G. \& Riesenberger, J., 2012. International business: New realities ( $3^{\text {rd }}$ edition). Pearson.

Cucculelli, M. \& Bettinelli, C., 2016. Corporate governance in family firms, learning and reaction to recession: Evidence from Italy. Futures, 75, pp. 92-103.

David, P.A. Hall, B.H. \& Toole, A.A., 2000. Is public $R \& D$ a complement or substitute for private $R \& D$ ? A review of the econometric evidence. Research Policy, 29(4), pp. 497-529.

Erkip, F. Kız1lgün, Ö. \& Akinci, G.M., 2014. Retailers' resilience strategies and their impacts on urban spaces in Turkey. Cities, 36, pp. 112-120.

Freedman, M. \& Kuhns, A., 2018. Supply-side subsidies to improve food access and dietary outcomes: Evidence from the New Markets Tax Credit. Urban Studies, 55(14), pp. 3234-3251.

García-Quevedo, J., 2004. Do public subsidies complement business R\&D? A meta-analysis of the econometric evidence. KYKLOS, 57(1), pp. 87-102.

Hud, M. \& Hussinger, K., 2015. The impact of $R \& D$ subsidies during the crisis. Research Policy, 44(10), pp. 1844-1855.

Mateut, S., 2018. Subsidies, financial constraints and firm innovative activities in emerging economies. Small Business Economics, 50(1), 131-162.

Resnikoff, N., 2014. Walmart benefits from billions in government subsidies: Study. [Online] Available at http://www.msnbc.com/msnbc/walmartgovernment-subsidies-study\#51652 [Accessed February 20, 2019].

Shoag, D. \& Veuger, S., 2018. Shops and the city: Evidence on local externalities and local government policy from big-box bankruptcies. Review of Economics \& Statistics, 100(3), pp. 440-453.

Wild, J.J. \& Wild, K.L., 2019. International business: The challenges of globalization $\left(9^{\text {th }}\right.$ edition $)$. Pearson.

Yunlu, D.G. \& Murphy, D.D., 2012. $R \& D$ intensity and economic recession: Investigating the moderating role of CEO characteristics. Journal of Leadership \& Organizational Studies, 19(3), pp. 284-293.

Zuniga-Vicente, J.A. Alonso-Borrego, C. Forcadell, F.J. \& Galan, J.I., 2014. Assessing the effect of public subsidies on firm $R \& D$ investment: A survey. Journal of Economic Surveys, 28(1), pp. 36-67. 